$\xi=-1$

\title{
Effect of Shear Reinforcement on the Structural Behaviour of the Reinforced Concrete Deep Beam
}

\author{
A. Sai Sri Vidyadhari ${ }^{1 *}$, G. Sri Harsha ${ }^{2}$ \\ ${ }^{1} P G$ student, Structural Engineering in Civil Engineering Department, Koneru Lakshmaiah Education \\ Foundation, Guntur - 522502, India \\ ${ }^{2}$ Assistant Professor, Civil Engineering Department, Koneru Lakshmaiah Educational Foundation, Guntur - 522502, India. \\ *Corresponding author E-mail: vidya.27594@gmail.com
}

\begin{abstract}
The present study explains about the behavior of Deep beams in both experimental and analytical aspect. Considering the maximum moment from the analytical analysis, the Deep beams are designed according to the IS-456[2000] codal provisions. The failure of deep beams is mainly due to shear, which is considered as a catastrophic failure and many studies are being done on their behavior, some studies concluded that strut-tie- method(STM) is most relevant, but the IS-456(2000) code has no provisions regarding the STM. So, in the present study, the reinforcement area obtained in conventional design of deep beams as per IS provisions were arranged in the form of truss. Thus, comparing the behavior of conventional reinforced Deep beams with truss configured Deep beams, and comparing experimental results with analytical results of Deep Beams. The results concluded that the truss reinforced Deep beams shown good results compared to Conventional Deep Beams and IS-456 code need to be updated for the deep beam design in various approaches.
\end{abstract}

Keywords: Catastrophic, Deep beam, Failures, Strut-Tie Method, Truss configuration.

\section{Introduction}

Different codes have various definitions to deep beams differently according to IS-456(2000) code, clause-29.1 Deep beam is defined based on their effective span to the overall depth (i.e. $\frac{l}{\mathrm{D}}$ ), if $\frac{l}{\mathrm{D}} \leq 2$ for simply supported beam, $\frac{l}{\mathrm{D}} \leq 2.5$ for continuous beam these conditions shall be satisfied to design.

Depending on the geometric proportions, the capacity depends mainly on their shear behaviour. To reduce deflection and the catastrophic behaviour, the factors to be considered are shear-span to depth ratio, effective length to depth ratio, effective beam depth, web reinforcement, type of loading, support conditions, concrete compressive strength.

In 1995 first shear failure[1] appeared in the storehouse at walkinair force depot. Many researchers started examining the shear behaviour of beams. In deep beams the failure is fatal. Researchers have been concentrated on the shear and load-bearing capacity of the beams with various parameters like shear \& flexural reinforcement, shear span to depth ratio, grade of concrete. Salamy[2] compared the experimental analysis of Deep beam using strut and tie model with the analytical model of the Deep beam using Finite element analysis software DIANA 8.1.2. The analysis concluded that the analytical value is approximately equal to 0.8 times experimental. Hence the cost of experimental analysis can be reduced through an analytical approach Faroque[3] conducted experimental analysis on Deep beams using various codes like ACI, CIRIA, IS codes. The results concluded that the IS code gives the maximum reinforcement required for all loading conditions when compared to other codes.
Appaiah et al.[4] investigated on 210 Deep beams, various shear strength models were prepared using various codes such as ACI318(STM) 2008, IS 456, BS 8110, ACI-318 (2015), EC (2004), AIK (1998), Zsutty (1968). The results concluded that the ACI318 (STM) 2008 is more efficient in shear strength. Thenmistokis[5] conducted numerical and analytical study on glulam beams with unreinforced and reinforced(gluing $0.15 \mathrm{~cm}$ thick steel plate at bottom edge). The $3 \mathrm{D}$ analysis is done in ANSYS the results concluded that failure of unreinforced is brittle and for reinforced is ductile. Hence the reinforced is much preferrable in construction. Abolfazal et al. [6]conducted experimental analysis to understand the behaviour of highstrength reinforced concrete deep beam. The proper arrangement of shear reinforcement will improve the ultimate shear strength, the rebars in the shear span middle region have more efficiency on strengthening of deep beams. The investigation concludes that the ACI code need to be revised.

\subsection{Application}

Deep beams are the structural member which play the prominent role in many s, such as in bunkers \& silos for storage of oils and gasses; in RCC water tanks as side walls; in large open halls or rooms to transfer loads; as pile caps in foundations; shear walls also act as deep beam when their dimensions are restricted. The Strut and tie method is used in deep beams, shear walls, pile caps, pier head. 


\subsection{Failures}

The failure in the deep beam is mainly due to shear. There are some common types of failures (Fig:1) in the beams are

Flexural failure: this occurs due to yielding of steel in tension or crushing of concrete due to compression.

Diagonal tension failure: this occurs due to tensile stresses of varying magnitude, hence results in shear or both shear \& bending may occur in all parts.

Shear - Tension failure: this occurs when there is a loss of bond Strength at flexural level due to cracks, hence the load transfer mechanism from concrete to steel is disturbed.

Shear - Compression failure: this occurs due to crushing of the concrete at loading points.
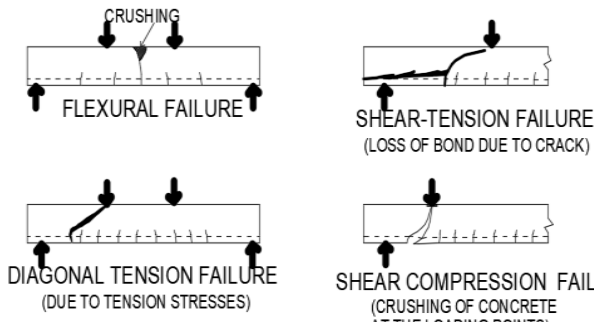

Fig 1: Types of failures in Deep Beams

\section{Analytical and Experimental Program}

In the present study a 10-storyed hotel building in Nellore was considered and modeled in Etabs, the various loads acting upon the hotel were calculated i.e. dead load using IS-875 (part-1)[7], wind load using IS-875 (part-3)[8], live load using IS-875 (part2)[9] were applied. From the analysis, the maximum moment occurred in a beam is considered i.e. $290 \mathrm{kN}-\mathrm{m}$ and the deep beam is designed for that moment as per IS-456 [10]code provisions The designed load of Deep beam is $829.3 \mathrm{kN}$. The mix design of the concrete obtained for $\mathrm{M}_{35}$ grade is 1:1.86:3.55. The reinforcement detailing of Deep beams is shown in the Fig:2, Fig:3 and Table:3, for both conventional reinforced deep beam(CDB) and truss reinforced deep beam(TDB).

Table 1: Compressive strength of cubes

\begin{tabular}{|l|l|l|l|l|}
\hline Specimen & CDB-1 & CDB-2 & TDB-1 & TDB-2 \\
\hline Load(kN) & 980 & 890 & 900 & 980 \\
\hline Load(kN) & 1000 & 960 & 1020 & 1100 \\
\hline Load(kN) & 930 & 910 & 980 & 930 \\
\hline $\begin{array}{l}\text { Compressive } \\
\text { strength(N/mm } \\
\text { = load / area }\end{array}$ & 42.292 & 40.11 & 42.15 & 43.75 \\
\hline
\end{tabular}

As many researchers said that strut and tie method of ACI code[11] is most efficient but costlier. So, in this study, the shear reinforcement obtained in the CDB is arranged in the form of truss shape. So that there is no increase in cost but the change is only the arrangement of reinforcement. In TDB, the angle of inclination taken is $45^{\circ}$. Because the angle between $35^{\circ}$ to $45^{\circ}$, it is considered as more economical and gives the most realistic design according to the ACI code. So, the angle of TDB is chosen as $45^{\circ}$. On CDB and TDB, Three-point loading is applied because the ACI code referred (Fig:4) that if the shear span $(\mathrm{a}=650 \mathrm{~mm}) \leq 2$ times its height or depth $(2 \mathrm{~h}=1600 \mathrm{~mm})$ then three-point loading is preferable. The shear effect is also dependent on the shear span i.e., shear effect increases with the increase in the shear span.

\subsection{Sketch indicating the Reinforcement detailing of the Deep Beams}

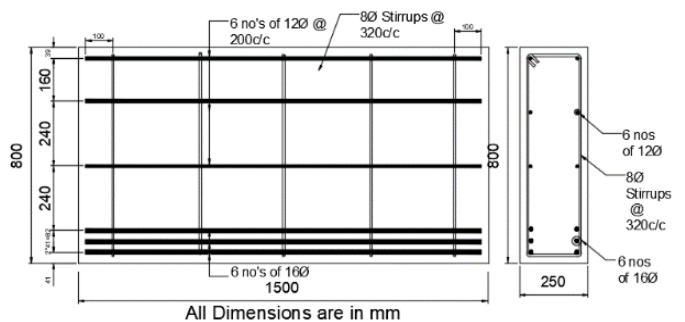

Fig 2: The detailing of reinforcement of Conventional

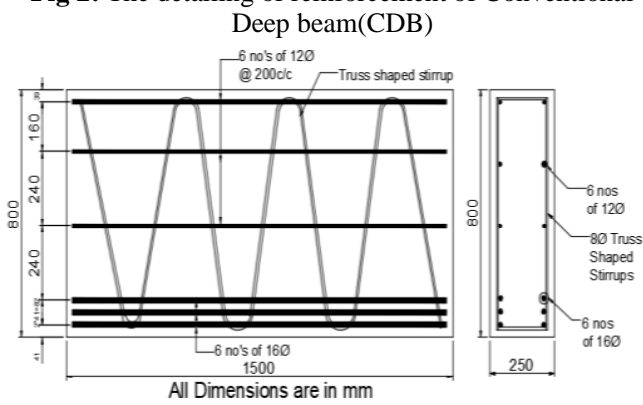

Fig 3: The detailing of Truss shaped reinforcement of Deep beam(TDB)

\subsection{Loading conditions for Deep beams as per ACI} code

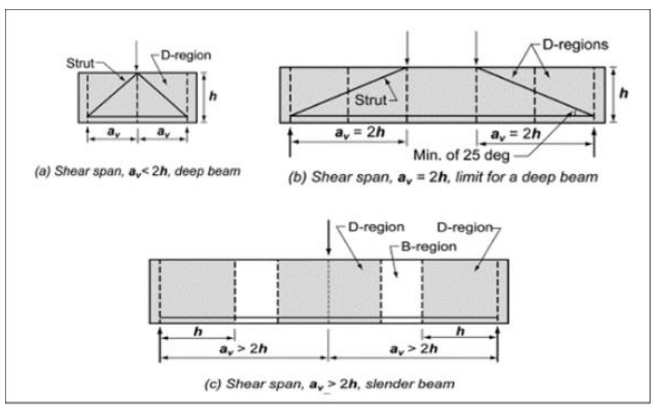

Fig 4: From ACI code the loading conditions

\section{Results and Discussions}

The specimens are tested under the loading frame with Three-point loading. The test setup is shown in the Fig:5 and the beam is under simply supported condition, the supports are placed on the supporting girders, on the supports $15 \mathrm{~cm}$ thick metal plates over which the beam is placed. From the top, the load cell will apply the point load on to the beam at center.

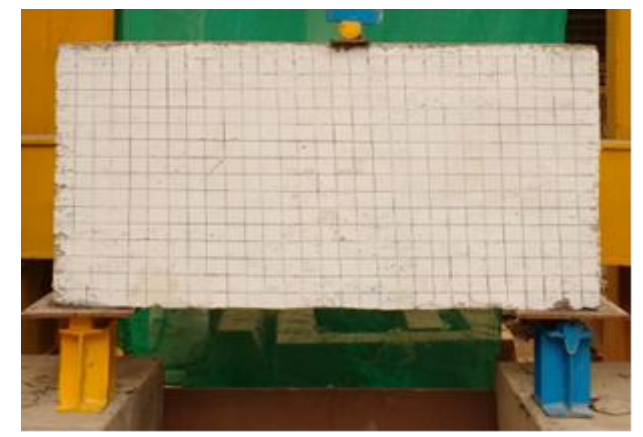

Fig 5: Experimental setup of the Deep Beam during loading 


\section{Crack pattern}

The specimens under the various loading were obtained from the readings of the LVDT (Linear Variable Differential Transducer) and the load from cell will be recorded automatically. The crack pattern of the CDB \& TDB is shown in Fig:5, the cracks propagated (shear cracks) from supports to the loading point at $45^{\circ}$. In CDB-1 the initial crack propagated at $536.8 \mathrm{kN}$ with $3.5 \mathrm{~mm}$ deflection, the peak load is observed as $920 \mathrm{kN}$ and the maximum crack width of $39 \mathrm{~mm}$ was occurred. In CDB-2 the initial crack was propagated at $786 \mathrm{kN}$ with $3.68 \mathrm{~mm}$ deflection, the peak load observed is $934 \mathrm{kN}$ and the maximum crack width of $22 \mathrm{~mm}$ was occurred. In TDB-1 the initial crack was propagated at $850 \mathrm{kN}$ with $2.6 \mathrm{~mm}$ deflection, the peak load observed is $980 \mathrm{kN}$, there is spalling of concrete at the loading point and the maximum crack width occurred is $2 \mathrm{~mm}$. In TDB-2 the initial crack was propagated at $800 \mathrm{kN}$ with $2.9 \mathrm{~mm}$ deflection, the peak load observed is $1142 \mathrm{kN}$ and the maximum crack width occurred is $37 \mathrm{~mm}$. The cracks were the shear cracks, which were propagated from the supports to the loading point (Fig.6 \&7).
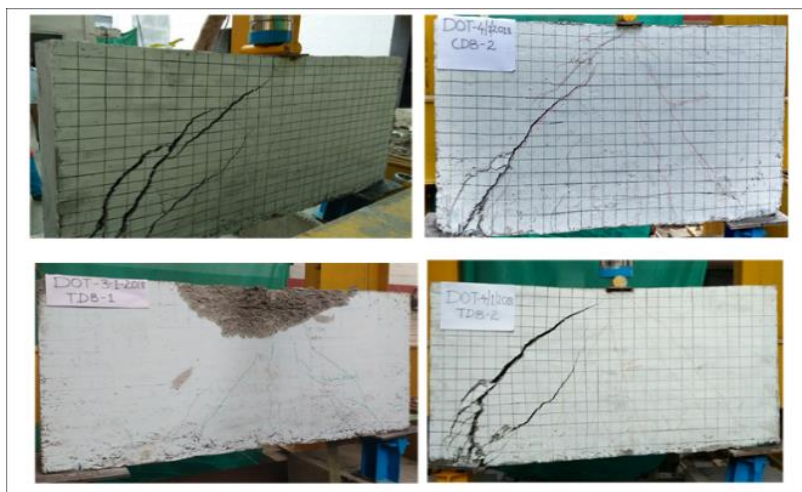

Fig 6: Crack Pattern in CDB \& TDB respectively

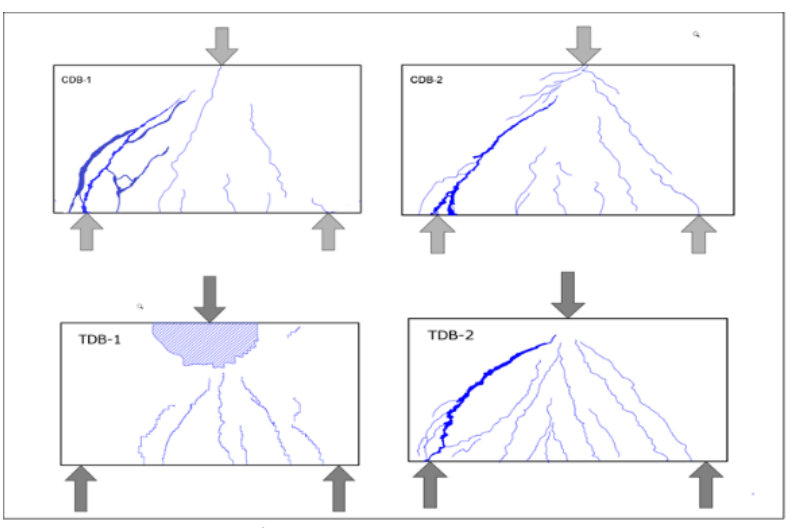

Fig 7: Digital Crack pattern

\subsection{Load Vs Displacement}

The applied load Vs displacement graphs for CDB and TDB is shown in Fig:8. The maximum load carrying capacity of the TDB is $1142 \mathrm{kN}$ at $5.04 \mathrm{~mm}$ deflection whereas the CDB the maximum load carrying capacity is $934 \mathrm{kN}$ at $6 \mathrm{~mm}$ deflection. It is clearly observed that the maximum load carrying capacity is more for the TDB when compared to CDB i.e. the truss configuration of shear reinforcement(TDB) has given the maximum load carrying. Also, the deflection is less in TDB compared to CDB. Hence the truss configuration of shear reinforcement is effective than the conventional.

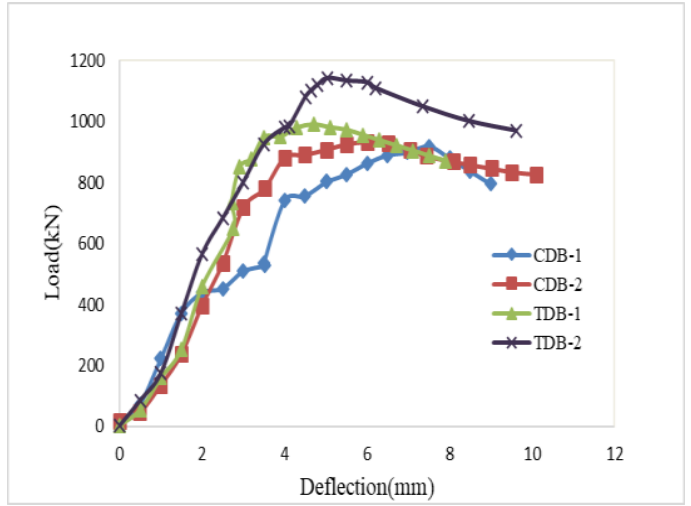

Fig 8: Load Vs Deflection graph

\subsection{Stress Vs Strain}

The loads acting on the beam will generate the shear force and moments, these (shear force and moments) in turn produces the stresses and strains in the beam. The Stress and Strain obtained in the CDB's \& TDB's indicated in Fig-9, from which we can conclude that the stresses developed in the TDB's is higher than the CDB's.

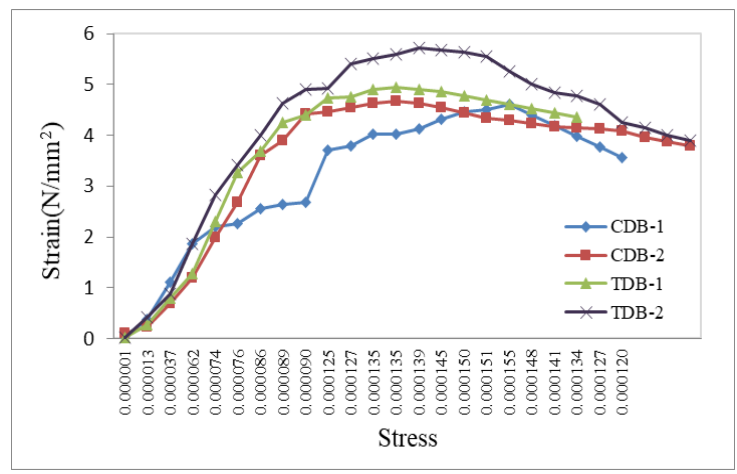

\section{Conclusions}

Fig 9: Stress Vs Strain graph

The following conclusions were drawn based on the experimental results.

1. The load carrying capacity of the TDB's is higher than the CDB's, at lowest deflection.

2. The Stresses developed in the TDB's is higher which indicates the load bearing capacity is high and strains developed at maximum stress in the TDB's is lesser i.e. deflection is less.

3. The stiffness of the TDS's is higher which indicates that the resistance to deformation is higher for TDB's compared to CDB's.

4. The Shear strength of the TDB's is higher i.e. the ability to withstand the effect of imposed load is higher for the TDB's.

5. The Moment generated in the TDB's is higher, hence they can withstand more forces.

6. There is no increases in the cost of construction as there is no change in quantity of rebars for both CDB's and TDB's. Only the arrangement of reinforcement is changed 


\section{References}

[1] F. Frp, CHAPTER 2, Literature Review- Shodhganga.

[2] M. R. Salamy and H. Kobayashi, 'Experimental and analytical study on rc deep beams', Asian Journal of Civil Engineering (Building and Housing), Vol. 6, No. 5, 2005, pp: 487-499.

[3] F. A. Faroque and R. Kumar, 'Comparison of design calculations of Deep beams using various International Codes', SSRG International Journal of Civil Engineering, Vol. 2, No. 10, 2015,pp: 18-26.

[4] Themistoklis Tsalkatidis, 'Numerical Simulation and Analytical study of Glulam Timber Beam', International Journal of Engineering Technology, Vol.3, No.2, 2014, pp: 129-136.

[5] K. Adinkrah-appiah and M. Adom-asamoah, 'Characterization and Shear Strength Prediction of Reinforced Concrete Deep Beams - A Review', International Journal of Science \& Recearch Vol. 5, No. 3, 2016, pp: 1789-1798.

[6] A.Arabzadeh, R. Aghayari, and A. R. Rahai, 'Investigation of experimental and analytical shear strength of reinforced concrete deep beams', Intrnational Journal of Science \& Recearch, Vol. 9, No. 3, 2011, pp:141-153.

[7] IS-875(part-1)-(1987), Indian Standered Code of Practice for Design Loads(other than Eatrhquake for Buildings and Structures)-Dead loads, Bureau of Indian Standards, Manak Bhavan, 9 Bahadur Shah Zafar Marg,New Delhi

[8] IS-875(part-2)-(1987), Indian Standered Code of Practice for Design Loads(other than Eatrhquake for Buildings and Structures)-Imposed loads, Bureau of Indian Standards, Manak Bhavan, 9 Bahadur Shah Zafar Marg,New Delhi.

[9] IS-875(part-3)-(1987), Indian Standered Code of Practice for Design Loads(other than Eatrhquake) for Buildings and Structures - Winid loads, Bureau of Indian Standards, Manak Bhavan, 9 Bahadur Shah Zafar Marg,New Delhi.

[10] IS-456(2000), Indian Standard code of practice- plain and Reinforced Concrete, $4^{\text {th }}$ revision, Bureau of Indian Standards, New Delhi.

[11] ACI-318(2008), Building Code Requirements for Structural Concrete and Commentary, American Concrete Institute: Farmington Hills, MI, USA.

[12] S. Ghuku and K.N. Saha, 'A Review on Stress and Deformation Analysis of Curved Beam under large Deflection', International Journal of Engineering Technology, Vol.11, No.13, 2017, pp:13-39. 